\title{
Locus Coeruleus Integrity in Older Adults with and without Chronic Pain
}

3 Tyler R. Bell, ${ }^{1,2}$ Carol E. Franz, ${ }^{1,2}$ Lisa T. Eyler, ${ }^{1}$ Christine Fennema-Notestine, ${ }^{1,2,3}$ Olivia K.

4 Puckett, ${ }^{1,2}$ Stephen M. Dorros, ${ }^{3}$ Matthew S. Panizzon, ${ }^{1,2}$ Rahul C. Pearce, ${ }^{1,2}$ Donald J. Hagler, ${ }^{1,3}$

5 Michael J. Lyons, ${ }^{4}$ Asad Beck, ${ }^{5}$ Jeremy A. Elman, ${ }^{1,2 *}$ William S. Kremen ${ }^{1,2 *}$

$7 \quad *$ Dr. Elman and Dr. Kremen are joint senior authors.

$9 \quad{ }^{1}$ Department of Psychiatry, University of California San Diego, San Diego, La Jolla, CA, 92093

$10{ }^{2}$ Center for Behavior Genetics of Aging, University of California, San Diego, La Jolla, CA,

1192093

$12{ }^{3}$ Department of Radiology, University of California San Diego, San Diego, La Jolla, CA, 92093

$13 \quad{ }^{4}$ Department of Psychology, Boston University, Boston, MA, USA, 02215

$14{ }^{5}$ Graduate Program in Neuroscience, University of Washington, Seattle, Washington, USA, 1598195 
medRxiv preprint doi: https://doi.org/10.1101/2021.11.02.21265820; this version posted November 3, 2021. The copyright holder for this preprint (which was not certified by peer review) is the author/funder, who has granted medRxiv a license to display the preprint in perpetuity.

All rights reserved. No reuse allowed without permission.

LOCUS COERULEUS AND CHRONIC PAIN

\section{Abstract}

21 The locus coeruleus (LC) is a brainstem region involved in regulating pain. Chronic pain is

22 common in older adulthood, but no studies have examined its association with the LC in humans.

23 We used neuromelanin-sensitive imaging to study differences in LC integrity in older adults with

24 and without chronic pain. Chronic pain was assessed in community-dwelling men from the

25 Vietnam Era Twin Study of Aging (VETSA) in 3 study waves covering an average of 12 years.

26 Pain was self-reported on the SF-36 Bodily Pain Scale. Chronic pain was defined as moderate to

27 severe pain severity at the current and at least one prior wave; $17 \%$ had chronic pain ( $n=80)$. At

28 the third wave, 481 participants (mean age=67.57) underwent neuromelanin-sensitive MRI scans

29 from which we calculated an LC contrast-to-noise ratio (LCCNR) - an index of LC integrity. We examined associations between chronic pain and LCCNR (in the rostral LC and caudal regions)

31 with generalized estimating equations after adjusting for age, race, education, depressive

32 symptoms, medical comorbidities, and opioid medication use. Individuals with chronic pain had .35 standard deviation lower rostral LCCNR (95\% CI: -.62 to -.05) compared to those without

34 chronic pain. No differences in the caudal LCCNR were detected. Chronic pain was associated with decreased rostral LC integrity in older adults. Differences in the rostral LC, rather than caudal LC, suggest the association between lower LC integrity and chronic pain may be related 
medRxiv preprint doi: https://doi.org/10.1101/2021.11.02.21265820; this version posted November 3, 2021. The copyright holder for this preprint (which was not certified by peer review) is the author/funder, who has granted medRxiv a license to display the preprint in perpetuity.

All rights reserved. No reuse allowed without permission.

LOCUS COERULEUS AND CHRONIC PAIN

\section{Introduction}

Approximately 27\%-33\% of older adults experience chronic pain, i.e., pain lasting three or more months [16]. Such pain is linked to increased risk of cognitive impairment [23,54], negative affective symptoms [2,12,27], sleep disruption [15], and reduced physical function in older adults [47]. Identifying brain regions related to chronic pain in older adults may help uncover reasons for poor pain modulation and other clinical symptoms. Human neuroimaging studies have found evidence of reduced gray matter volume and white matter integrity [2;10]. Animal studies suggest that the brainstem might also play an important role in pain [33]. However, this region has not been examined in pain studies of humans. A brainstem region of particular interest is the locus coeruleus (LC), a small nucleus $\left(30-60 \mathrm{~mm}^{3}\right)$ that serves as the central projection site for norepinephrine (NE) [49].

The LC is essential to acute pain processing. After tissue damage, nociceptive signals are gated (allowed to ascend or not) at inter-neuronal spaces throughout the dorsal horn and further modulated by caudal LC projections to pre- and post-synaptic terminals [37]. Nociceptive signals received by the caudal LC then modulate sensory and affective pain processing in cortical regions. Sensory pain processing involves caudal and rostral LC-NE projections to the thalamus and parietal cortices that determine whether one feels pain and where. Affective pain processing involves rostral LC-NE projections to the prefrontal cortex, amygdala, and insula [38] that determine how one feels and responds to pain. Because of the essential roles of the LC in acute pain processing, chronic pain may involve poorer structural integrity of this region [43].

Different theories of chronic pain and neurodegeneration may suggest how chronic pain and LC integrity may be associated. Active theory suggests that pain initiates signaling from the spinal cord to the brain that in turn results in neuroinflammatory processes and brain atrophy, 
medRxiv preprint doi: https://doi.org/10.1101/2021.11.02.21265820; this version posted November 3, 2021. The copyright holder for this preprint (which was not certified by peer review) is the author/funder, who has granted medRxiv a license to display the preprint in perpetuity.

All rights reserved. No reuse allowed without permission.

\section{LOCUS COERULEUS AND CHRONIC PAIN}

64 due to increased cytokine levels [26,31,52] and/or increased tau and beta-amyloid formation

$65[13,17,24,25]$. Passive theory posits that many age-associated neurodegenerative diseases harm

pain-processing brain regions, a consequence of which is the experience of chronic pain. Chronic

67 pain following major neurodegenerative diseases such as dementia, Parkinson’s disease, and

that early brain characteristics put people at risk for chronic pain due to poor pain modulation, as shown in prospective studies $[5,50]$.

Here we examined the association between chronic pain and LC integrity in older adults for the first time. LC structural integrity was based on an MRI measure of neuromelanin signal [33]. We hypothesized that people with chronic pain would show lower LC integrity compared to people without chronic pain. We examined the rostral and caudal LC regions separately, given the importance of their respective connections to cortical sensory/affective pain processing and nociceptive gating in the dorsal horn [42]. Neuromelanin signals from the middle LC were combined with the rostral signals as both regions have overlapping projection sites and similar changes related to age and neurodegenerative disease [9,10,37].

\section{Methods}

\section{Participants}

Participants were from the Vietnam Era Twin Study of Aging (VETSA), a longitudinal study of male twins assessed at average ages 56, 62, and 68 - an approximately 12-year time span [34]. All participants served in the military at some time during the Vietnam era (19651975). The majority did not serve in Southeast Asia, and about $80 \%$ reported no combat exposure. This sample is representative of general community-dwelling men in their age range on demographics, health, and other lifestyle factors based on Centers for Disease Control and 
medRxiv preprint doi: https://doi.org/10.1101/2021.11.02.21265820; this version posted November 3, 2021. The copyright holder for this preprint (which was not certified by peer review) is the author/funder, who has granted medRxiv a license to display the preprint in perpetuity.

All rights reserved. No reuse allowed without permission.

\section{LOCUS COERULEUS AND CHRONIC PAIN}

87 Prevention data [44]. Previous studies have described the methodology and available data in the

VETSA project [34,35]. Data are publicly accessible to researchers through data authorization

89 (http://www.vetsatwins.org/for-researchers/). Procedures of the VETSA were approved by the

90 Institutional Review Boards at the University of California, San Diego, and Boston University.

LC imaging was introduced at wave 3 (2016 to 2019). Of eligible MRI participants, 485

92 (92.4\%) met standard MRI inclusion criteria (e.g., no metal in the body) and completed imaging

of the LC. Four were excluded due to poor image quality. The final sample consisted of 481

94 individuals with an average age of 67.52 years $(S D=2.60$, range $=61.96$ to 71.72$)$.

95 Demographic characteristics of this sample can be seen in Table 1.

Measures

\section{Chronic pain}

Pain was assessed using the SF-36 Quality of Life (Version 1.0) Bodily Pain Scale [53],

99 which was given at each assessment wave. Specifically, we used the pain severity item

100 (Question 22) asking participants, "How much pain severity have you had during the past 4

101 weeks”. Severity was rated on a 6-point Likert-type scale from “None” (1), "Very Mild”

102

(2),“Mild” (3),“Moderate” (4),“Severe” (5),“Very Severe” (6). Chronic pain was defined as

moderate to very severe pain (values 4-6 on the scale) at wave 3 and the previous participating

104

wave. Pain reported over two or more waves (approximately 6 to 12 years) fits common

105

definitions of chronic pain as moderate to severe pain severity [32] that lasts 3 or more months

106 [16]. People with no pain or pain during only one wave were classified as not having chronic

107 pain. 
medRxiv preprint doi: https://doi.org/10.1101/2021.11.02.21265820; this version posted November 3, 2021. The copyright holder for this preprint (which was not certified by peer review) is the author/funder, who has granted medRxiv a license to display the preprint in perpetuity.

All rights reserved. No reuse allowed without permission.

\section{LOCUS COERULEUS AND CHRONIC PAIN}

\section{LC MRI Acquisition and Processing}

We previously described our procedures for MRI imaging of the LC [20]. In brief, participants completed scans in GE 3T Discovery 750x scanners (GE Healthcare, Waukesha, WI, USA) with an eight-channel phased-array head coil. Oblique axial FSE-T1-weighted images

were then obtained $\left(\mathrm{TR}=600 \mathrm{~ms} ; \mathrm{TE}=14 \mathrm{~ms}\right.$; flip angle $=90^{\circ}$; matrix $=512 \times 320 ; \mathrm{FOV}=220$ mm; pixel size $0.42 \times 0.68 \mathrm{~mm}$; 10 slices; slice thickness $=2.5 \mathrm{~mm}$; interslice gap $=1 \mathrm{~mm}$ ). Each image was manually marked by two of four experienced raters according to methods described in detail previously [22]. Briefly, signal intensities were derived from manually marked regions of interest (ROIs) on three axially oriented slices corresponding to rostral, middle, and caudal LC. On each slice, a 3mm²-voxel crosshair-shaped ROI was placed over left and right LC and a $10 \mathrm{~mm}^{2}$ square reference ROI was placed in the pontine tegmentum (PT). Mean signal was then extracted from each ROI. The values from left and right LC were highly correlated (rs > .98) and were subsequently averaged for each slice. Finally, LC contrastto-noise ratio $\left(\mathrm{LC}_{\mathrm{CNR}}\right)$ values were calculated for each slice as $\mathrm{LC}_{\mathrm{CNR}}=\left(\mathrm{LC}_{\text {intensity }}\right.$ PTintensity)/PTintensity. Higher LCcNR values are thought to reflect better LC structural integrity [33]. For each individual, we calculated the rostral and caudal LCCNR: we averaged LCCNR

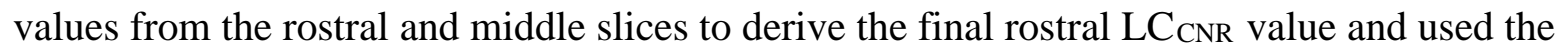
LC CNR value from the caudal marked slice to derive the final caudal LC CNR value.

\section{Covariates}

Variables that could confound an association between chronic pain and LCCNR were included as covariates. These included age, race/ethnicity (non-Hispanic white versus other), education (years), depressive symptoms indexed using the 20-item Center of Epidemiological Studies scale (CES-D) [40], medical comorbidities (total number of reported major health 
medRxiv preprint doi: https://doi.org/10.1101/2021.11.02.21265820; this version posted November 3, 2021. The copyright holder for this preprint (which was not certified by peer review) is the author/funder, who has granted medRxiv a license to display the preprint in perpetuity.

All rights reserved. No reuse allowed without permission.

\section{LOCUS COERULEUS AND CHRONIC PAIN}

132 conditions from a modified Charlson Index [14]), and the use of opioid medication based on

133 reports of medications taken in the medical history interview (yes/no).

\section{Statistical Analysis}

Descriptive statistics are shown in Table 1, and we compared key covariates between people with and without chronic pain to identify potential confounding variables. General estimating equations (GEEs) using unstructured correlation matrices were conducted using SAS (version 9.4) to examine the association between chronic pain and $\mathrm{LC}_{\mathrm{CNR}}$, providing effect estimates while accounting for the correlation of observations within twin pairs. Separate models were conducted for rostral and caudal LC CNR with each outcome regressed onto chronic pain

141 status and adjusted for covariates. Statistical significance was set to an $\alpha$ of .05, and 95\%

142 confidence intervals were calculated. Models were conducted using bootstrapping with 1000 143 resamples to provide robust estimates.

\section{Results}

\section{Descriptive Statistics}

In participants completing LCCNR measurement, $16.6 \%(n=80)$ reported chronic pain.

147 Compared with individuals who did not report chronic pain, participants reporting chronic pain 148 had more depressive symptoms $(t(97.44)=4.30, p<.001, d=.87)$, more medical comorbidities

$149(t(98.26)=5.16, p=.013, d=1.04)$, and were more likely to be using opioid medications $\left(\chi^{2}(1)\right.$ $150=25.67, p<.001, \eta^{2}=.23 ; 16.3 \%$ versus $2.8 \%$ ), but did not differ in age $(p=.069)$.

\section{Main Results}


medRxiv preprint doi: https://doi.org/10.1101/2021.11.02.21265820; this version posted November 3, 2021. The copyright holder for this preprint (which was not certified by peer review) is the author/funder, who has granted medRxiv a license to display the preprint in perpetuity.

All rights reserved. No reuse allowed without permission.

\section{LOCUS COERULEUS AND CHRONIC PAIN}

154

155

156

157

158

159

160

161

162

163

164

165

166

167

168

169

170

171

172

173

174

175

176

Of the covariates, older age was associated with lower rostral LCCNR $(b=-.04,95 \%$ CI: -.05 to $.01, \beta=-.13, p=.027)$. Race/ethnicity, education, depressive symptoms, medical comorbidities, and opioid use were not significantly associated with rostral LCCNR ( $p s>.05)$.

As shown in Table 3 and Figure 1, participants with chronic pain did not differ from participants without chronic pain on caudal LCCNR $(p=.755)$. No covariate was significantly associated with caudal LCCNR ( $p s>.05)$.

integrity in older adults. Overall, individuals with chronic pain had lower structural integrity in the rostral LC compared to those without chronic pain. This difference was not accounted for by age, depressive symptoms, medical comorbidities, or opioid use. No significant associations were observed for the caudal LC region. To our knowledge, this is the first examination of associations between chronic pain and LC integrity in humans.

An association between chronic pain and rostral LC integrity adds to previous literature implicating the LC in human pain modulation. Anatomical studies have linked the LC to several important brain regions involved in sensory and affective pain processing, and the LC has connections to the dorsal horn of the spine where nociceptive signals are gated [37]. Animal studies have shown a causal role of the LC in pain modulation. In rats, for example, stimulation of the LC suppresses pain while lesions to the LC increase pain sensitivity [37]. Other studies found that drugs that target the LC-NE system through gabapentinoids [28] and serotoninnorepinephrine reuptake inhibitors markedly inhibit neuropathic pain in rats with ablated or constricted nerve injury [1]. Such effects can be reversed with the application of NE antagonists [28]. Early evidence consistent with the LC-NE system’s role in human pain comes from 
medRxiv preprint doi: https://doi.org/10.1101/2021.11.02.21265820; this version posted November 3, 2021. The copyright holder for this preprint (which was not certified by peer review) is the author/funder, who has granted medRxiv a license to display the preprint in perpetuity.

All rights reserved. No reuse allowed without permission.

\section{LOCUS COERULEUS AND CHRONIC PAIN}

177 successful treatment with similar medications $[4,46]$. Although our study cannot determine

178 causation, our findings are consistent with evidence that the LC is related to human pain.

Results were region-specific. Caudal LC integrity was not different in people with

chronic pain compared to people without chronic pain. As mentioned, the rostral LC has more

projection sites to cortical regions involved in the sensory and affective processing of pain, while

chronic pain [31], our study suggests that the rostral region is most related to chronic pain in humans.

Although chronic pain classification was based on longitudinal data at two earlier waves,

that lower rostral LC integrity is a consequence of global brain atrophy related to chronic pain

195 affected be neurodegenerative diseases, which may make the LC vulnerable. For example, 196 Alzheimer's disease is characterized by pathology in the LC at its earliest stages [11]. Lastly,

197 lower rostral LC integrity could represent differences from earlier brain development, making 
medRxiv preprint doi: https://doi.org/10.1101/2021.11.02.21265820; this version posted November 3, 2021. The copyright holder for this preprint (which was not certified by peer review) is the author/funder, who has granted medRxiv a license to display the preprint in perpetuity.

All rights reserved. No reuse allowed without permission.

\section{LOCUS COERULEUS AND CHRONIC PAIN}

200

201

theories. However, directionality and causation remain to be resolved with longitudinal assessment and experimental animal modeling.

Our measure of LC integrity may have functional implications to consider, especially if lower integrity reflects structural degeneration. Damaged LC regions produce more tonic levels of NE to projections sites which activate pain-processing brain regions [3,30,51]. In animal models, tonic NE release from the LC has been shown to promotes affective pain processing in the amygdala and anterior cingulate cortex specifically [55]. This has also been shown to result from inducing pain-related injury [48]. Increased tonic LC-NE outputs could explain why people with chronic pain show more tonic pupillary responses [8,39], which correlate with greater pain intensity generally [29]. Although more work will be needed to discern NE patterns, it could be that people with chronic pain have higher tonic discharge relating to lower rostral LC integrity, thereby increasing cortical pain processing. Put another way, the link between chronic pain and rostral, but not caudal, LC integrity suggests more top-down rather than bottom-up regulation of the response to pain.

Our finding that older adults with persistent pain have lower rostral LC integrity might explain other pain-related symptoms. In particular, the LC is a key structure involved in arousal and modulation of cognitive function. For example, our previous work in this sample showed that people with lower rostral LC integrity had greater daytime sleep-related dysfunction [21] - a symptom frequently reported in people with chronic pain [19]. Furthermore, people with chronic pain have worse cognitive performance than those without chronic pain [6,7]. Our prior work has shown better rostral LC integrity may be related to better cognitive performance and reduced risk of amnestic mild cognitive impairment [21]. In other studies, lower LC integrity has also been associated with major depressive disorder [45], a condition more common in people with chronic 


\section{LOCUS COERULEUS AND CHRONIC PAIN}

223 pain. As such, LC integrity might play a role in other phenomena associated with chronic pain,

224 although the causal direction of the LC-pain association or the associations of chronic pain with other LC-related phenomena remains unclear.

Our study has some limitations and strengths. First, as mentioned, we cannot address causality, although evidence thus far suggests that the relationship may be bidirectional. Also, we cannot ascertain the pathology contributing to lower LC integrity in this population without histological data, although inflammatory processes are suspected. Secondly, our sample is entirely male and primarily non-Hispanic white, making generalizability to women and racial/ethnic minorities uncertain. Regarding strengths, we used a novel MRI approach to

232 provide one of the first in vivo analyses of chronic pain and LC integrity while adjusting for several possible confounding factors.

Chronic pain is a costly condition in later life, reducing quality of life, cognitive function, and physical abilities. Identifying the biological mechanisms behind its inception and continuation is thus a worthwhile goal and could identify potential treatment targets to promote

237 healthier aging trajectories. Such work is of increasing importance as the number of adults over age 65 will triple by 2050, along with cases of chronic pain [41]. Our study adds to previous

239 findings linking the LC and pain, showing that older adults with chronic pain have lower rostral

241 using neuromelanin MRI imaging and further animal modeling will be crucial, especially for

242 determining the role of exact pathways and LC-NE discharge patterns.

243 Author contributions: Description of authors’ roles: All authors contributed to the conception 
medRxiv preprint doi: https://doi.org/10.1101/2021.11.02.21265820; this version posted November 3, 2021. The copyright holder for this preprint (which was not certified by peer review) is the author/funder, who has granted medRxiv a license to display the preprint in perpetuity.

All rights reserved. No reuse allowed without permission.

\section{LOCUS COERULEUS AND CHRONIC PAIN}

245 helped to revise the work for intellectual content and approved the final draft. All authors are

246 accountable for all aspects of the work ensuring accuracy and integrity.

247 Sponsors' role: This work was supported by the National Institute on Aging at the National 248 Institutes of Health grant numbers R01s AG050595, AG022381, AG037985, AG062483, and 249 P01 AG055367, and K01AG063805.

250 Acknowledgments: The content is the responsibility of the authors and does not necessarily 251 represent official views of the NIA, NIH, or VA. The U.S. Department of Veterans Affairs, 252 Department of Defense; National Personnel Records Center, National Archives and Records 253 Administration; National Opinion Research Center; National Research Council, National 254 Academy of Sciences; and the Institute for Survey Research, Temple University provided 255 invaluable assistance in the creation of the VET Registry. The Cooperative Studies Program of 256 the U.S. Department of Veterans Affairs provided financial support for development and 257 maintenance of the Vietnam Era Twin Registry. We would also like to acknowledge the 258 continued cooperation and participation of the members of the VET Registry and their families.

Data availability: VETSA data can be accessed through data requests submitted online

260 (http://www.vetsatwins.org/for-researchers/). Request for additional information regarding the 261 specific use of data and data analytic methods may be sent to the first author.

262 Conflict of Interest Declaration: The authors declare the absence of known competing financial or personal relationships that could have influenced the work reported in this paper. 
medRxiv preprint doi: https://doi.org/10.1101/2021.11.02.21265820; this version posted November 3, 2021. The copyright holder for this preprint (which was not certified by peer review) is the author/funder, who has granted medRxiv a license to display the preprint in perpetuity.

All rights reserved. No reuse allowed without permission.

LOCUS COERULEUS AND CHRONIC PAIN

\section{References}

267

268

269

270

271

272

273

274

275

276

277

278

279

280

281

282

283

284

285

286

[1] Alba-Delgado C, Mico JA, Sanchez-Blazquez P, Berrocoso E. Analgesic antidepressants

promote the responsiveness of locus coeruleus neurons to noxious stimulation:

Implications for neuropathic pain. Pain 2012;153(7):1438-1449.doi:

10.1016/j.pain.2012.03.034

[2] Arola H-M, Nicholls E, Mallen C, Thomas E. Self-reported pain interference and symptoms of anxiety and depression in community-dwelling older adults: Can a temporal relationship be determined? European Journal of Pain 2010;14(9):966-971.doi: https://doi.org/10.1016/j.ejpain.2010.02.012

[3] Aston-Jones G, Cohen JD. An integrative theory of locus coeruleus-norepinephrine function: adaptive gain and optimal performance. Annu Rev Neurosci 2005;28:403-450.doi: 10.1146/annurev.neuro.28.061604.135709

[4] Backonja M, Glanzman RL. Gabapentin dosing for neuropathic pain: Evidence from randomized, placebo-controlled clinical trials. Clin Ther 2003;25(1):81-104.doi: 10.1016/s0149-2918(03)90011-7

[5] Baliki MN, Petre B, Torbey S, Herrmann KM, Huang L, Schnitzer TJ, Fields HL, Apkarian AV. Corticostriatal functional connectivity predicts transition to chronic back pain. Nat Neurosci 2012;15(8):1117-1119.doi: 10.1038/nn.3153

[6] Berryman C, Stanton TR, Bowering KJ, Tabor A, McFarlane A, Moseley GL. Do people with chronic pain have impaired executive function? A meta-analytical review. Clin Psychol Rev 2014;34(7):563-579.doi: 10.1016/j.cpr.2014.08.003 
medRxiv preprint doi: https://doi.org/10.1101/2021.11.02.21265820; this version posted November 3, 2021. The copyright holder for this preprint (which was not certified by peer review) is the author/funder, who has granted medRxiv a license to display the preprint in perpetuity. All rights reserved. No reuse allowed without permission.

\section{LOCUS COERULEUS AND CHRONIC PAIN}

287 [7] Berryman C, Stanton TR, Jane Bowering K, Tabor A, McFarlane A, Lorimer Moseley G. Evidence for working memory deficits in chronic pain: A systematic review and metaanalysis. Pain 2013;154(8):1181-1196.doi: 10.1016/j.pain.2013.03.002

290

291

292

293

294

295

296

297

298

299

300

301

302

303

304

305

306

307

308

[8] Bertinotti L, Pietrini U, Del Rosso A, Casale R, Colangelo N, Zoppi M, Matucci-Cerinic M. The use of pupillometry in joint and connective tissue diseases. Neuroendocrine Immune Basis of the Rheumatic Diseases Ii, Proceedings 2002;966(1):446-455.doi: DOI 10.1111/j.1749-6632.2002.tb04246.x

[9] Betts MJ, Cardenas-Blanco A, Kanowski M, Spottke A, Teipel SJ, Kilimann I, Jessen F, Duzel E. Locus coeruleus MRI contrast is reduced in Alzheimer's disease dementia and correlates with CSF Abeta levels. Alzheimers Dement (Amst) 2019;11:281-285.doi: 10.1016/j.dadm.2019.02.001

[10] Betts MJ, Kirilina E, Otaduy MCG, Ivanov D, Acosta-Cabronero J, Callaghan MF, Lambert C, Cardenas-Blanco A, Pine K, Passamonti L, Loane C, Keuken MC, Trujillo P, Lusebrink F, Mattern H, Liu KY, Priovoulos N, Fliessbach K, Dahl MJ, Maass A, Madelung CF, Meder D, Ehrenberg AJ, Speck O, Weiskopf N, Dolan R, Inglis B, Tosun D, Morawski M, Zucca FA, Siebner HR, Mather M, Uludag K, Heinsen H, Poser BA, Howard R, Zecca L, Rowe JB, Grinberg LT, Jacobs HIL, Duzel E, Hammerer D. Locus coeruleus imaging as a biomarker for noradrenergic dysfunction in neurodegenerative diseases. Brain 2019;142(9):2558-2571.doi: 10.1093/brain/awz193

[11] Braak H, Thal DR, Ghebremedhin E, Del Tredici K. Stages of the pathologic process in Alzheimer disease: Age categories from 1 to 100 years. J Neuropathol Exp Neurol 2011;70(11):960-969.doi: 10.1097/NEN.0b013e318232a379 
medRxiv preprint doi: https://doi.org/10.1101/2021.11.02.21265820; this version posted November 3, 2021. The copyright holder for this preprint (which was not certified by peer review) is the author/funder, who has granted medRxiv a license to display the preprint in perpetuity. All rights reserved. No reuse allowed without permission.

LOCUS COERULEUS AND CHRONIC PAIN

[12] Burke AL, Mathias JL, Denson LA. Psychological functioning of people living with chronic pain: A meta-analytic review. Br J Clin Psychol 2015;54(3):345-360.doi: 10.1111/bjc.12078

[13] Cao S, Fisher DW, Yu T, Dong H. The link between chronic pain and Alzheimer's disease. J Neuroinflammation 2019;16(1):204.doi: 10.1186/s12974-019-1608-z

[14] Charlson M, Szatrowski TP, Peterson J, Gold J. Validation of a combined comorbidity index. J Clin Epidemiol 1994;47(11):1245-1251.doi: 10.1016/0895-4356(94)90129-5

[15] Chen Q, Hayman LL, Shmerling RH, Bean JF, Leveille SG. Characteristics of chronic pain associated with sleep difficulty in older adults: the Maintenance of Balance, Independent Living, Intellect, and Zest in the Elderly (MOBILIZE) Boston study. J Am Geriatr Soc 2011;59(8):1385-1392.doi: 10.1111/j.1532-5415.2011.03544.x

[16] Dahlhamer J, Lucas J, Zelaya C, Nahin R, Mackey S, DeBar L, Kerns R, Von Korff M, Porter L, Helmick C. Prevalence of chronic pain and high-impact chronic pain among adults - United States, 2016. Mmwr-Morbidity and Mortality Weekly Report 2018;67(36):1001-1006.doi: DOI 10.15585/mmwr.mm6736a2

[17] Dani M, Wood M, Mizoguchi R, Fan Z, Walker Z, Morgan R, Hinz R, Biju M, Kuruvilla T, Brooks DJ, Edison P. Microglial activation correlates in vivo with both tau and amyloid in Alzheimer's disease. Brain 2018;141(9):2740-2754.doi: 10.1093/brain/awy188

[18] De Tommaso M, Arendt-Nielsen L, Defrin R, Kunz M, Pickering G, Valeriani M. Pain in neurodegenerative disease: current knowledge and future perspectives. Behavioural neurology 2016;2016.doi:

[19] Eccles JA, Davies KA. The challenges of chronic pain and fatigue. Clin Med (Lond) 2021;21(1):19-27.doi: 10.7861/clinmed.2020-1009 


\section{LOCUS COERULEUS AND CHRONIC PAIN}

[20] Elman JA, Panizzon MS, Hagler DJ, Jr., Eyler LT, Granholm EL, Fennema-Notestine C, Lyons MJ, McEvoy LK, Franz CE, Dale AM, Kremen WS. Task-evoked pupil dilation and BOLD variance as indicators of locus coeruleus dysfunction. Cortex 2017;97:6069.doi: 10.1016/j.cortex.2017.09.025

[21] Elman JA, Puckett OK, Beck A, Fennema-Notestine C, Cross LK, Dale AM, Eglit GML, Eyler LT, Gillespie NA, Granholm EL, Gustavson DE, Hagler DJ, Hatton SN, Hauger R, Jak AJ, Logue MW, McEvoy LK, McKenzie RE, Neale MC, Panizzon MS, Reynolds CA, Sanderson-Cimino M, Toomey R, Tu XM, Whitsel N, Williams ME, Xian H, Lyons MJ, Franz CE, Kremen WS. MRI-assessed locus coeruleus integrity is heritable and associated with multiple cognitive domains, mild cognitive impairment, and daytime dysfunction. Alzheimers \& Dementia 2021;17(6):1017-1025.doi: 10.1002/alz.12261

[22] Elman JA, Puckett OK, Beck A, Fennema-Notestine C, Cross LK, Dale AM, Eglit GML, Eyler LT, Gillespie NA, Granholm EL, Gustavson DE, Hagler DJ, Jr., Hatton SN, Hauger R, Jak AJ, Logue MW, McEvoy LK, McKenzie RE, Neale MC, Panizzon MS, Reynolds CA, Sanderson-Cimino M, Toomey R, Tu XM, Whitsel N, Williams ME, Xian H, Lyons MJ, Franz CE, Kremen WS. MRI-assessed locus coeruleus integrity is heritable and associated with multiple cognitive domains, mild cognitive impairment, and daytime dysfunction. Alzheimers Dement 2021.doi: 10.1002/alz.12261

[23] Ezzati A, Wang C, Katz MJ, Derby CA, Zammit AR, Zimmerman ME, Pavlovic JM, Sliwinski MJ, Lipton RB. The temporal relationship between pain intensity and pain interference and incident dementia. Curr Alzheimer Res 2019;16(2):109-115.doi: $10.2174 / 1567205016666181212162424$ 
medRxiv preprint doi: https://doi.org/10.1101/2021.11.02.21265820; this version posted November 3, 2021. The copyright holder for this preprint (which was not certified by peer review) is the author/funder, who has granted medRxiv a license to display the preprint in perpetuity. All rights reserved. No reuse allowed without permission.

LOCUS COERULEUS AND CHRONIC PAIN

[24] Ghosh S, Wu MD, Shaftel SS, Kyrkanides S, LaFerla FM, Olschowka JA, O'Banion MK. Sustained interleukin-1beta overexpression exacerbates tau pathology despite reduced amyloid burden in an Alzheimer's mouse model. J Neurosci 2013;33(11):5053-5064.doi: 10.1523/JNEUROSCI.4361-12.2013

[25] Gill J, Mustapic M, Diaz-Arrastia R, Lange R, Gulyani S, Diehl T, Motamedi V, Osier N, Stern RA, Kapogiannis D. Higher exosomal tau, amyloid-beta 42 and IL-10 are associated with mild TBIs and chronic symptoms in military personnel. Brain Inj 2018;32(10):1277-1284.doi: 10.1080/02699052.2018.1471738

[26] Hains BC, Waxman SG. Activated microglia contribute to the maintenance of chronic pain after spinal cord injury. J Neurosci 2006;26(16):4308-4317.doi: 10.1523/JNEUROSCI.0003-06.2006

[27] Hawker GA, Gignac MA, Badley E, Davis AM, French MR, Li Y, Perruccio AV, Power JD, Sale J, Lou W. A longitudinal study to explain the pain-depression link in older adults with osteoarthritis. Arthritis Care Res (Hoboken) 2011;63(10):1382-1390.doi: 10.1002/acr.20298

[28] Hayashida KI, Obata H, Nakajima K, Eisenach JC. Gabapentin acts within the locus coeruleus to alleviate neuropathic pain. Anesthesiology 2008;109(6):1077-1084.doi: 10.1097/ALN.0b013e31818dac9c

[29] Höfle M, Kenntner-Mabiala R, Pauli P, Alpers GW. You can see pain in the eye: Pupillometry as an index of pain intensity under different luminance conditions. International Journal of Psychophysiology 2008;70(3):171-175.doi: https://doi.org/10.1016/j.ijpsycho.2008.06.008 
medRxiv preprint doi: https://doi.org/10.1101/2021.11.02.21265820; this version posted November 3, 2021. The copyright holder for this preprint (which was not certified by peer review) is the author/funder, who has granted medRxiv a license to display the preprint in perpetuity. All rights reserved. No reuse allowed without permission.

\section{LOCUS COERULEUS AND CHRONIC PAIN}

[30] Howells FM, Stein DJ, Russell VA. Synergistic tonic and phasic activity of the locus coeruleus norepinephrine (LC-NE) arousal system is required for optimal attentional performance. Metabolic Brain Disease 2012;27(3):267-274.doi: 10.1007/s11011-0129287-9

[31] Ji RR, Nackley A, Huh Y, Terrando N, Maixner W. Neuroinflammation and central sensitization in chronic and widespread pain. Anesthesiology 2018;129(2):343-366.doi: 10.1097/ALN.0000000000002130

[32] Johannes CB, Le TK, Zhou X, Johnston JA, Dworkin RH. The prevalence of chronic pain in United States adults: Results of an Internet-based survey. J Pain 2010;11(11):12301239.doi: 10.1016/j.jpain.2010.07.002

[33] Keren NI, Taheri S, Vazey EM, Morgan PS, Granholm AC, Aston-Jones GS, Eckert MA. Histologic validation of locus coeruleus MRI contrast in post-mortem tissue. Neuroimage 2015;113:235-245.doi: 10.1016/j.neuroimage.2015.03.020

[34] Kremen WS, Franz CE, Lyons MJ. VETSA: the Vietnam Era Twin Study of Aging. Twin Res Hum Genet 2013;16(1):399-402.doi: 10.1017/thg.2012.86

[35] Kremen WS, Franz CE, Lyons MJ. Current status of the Vietnam Era Twin Study of Aging (VETSA). Twin Res Hum Genet 2019;22(6):783-787.doi: 10.1017/thg.2019.125

[36] Li J, Simone DA, Larson AA. Windup leads to characteristics of central sensitization. Pain 1999;79(1):75-82.doi: 10.1016/S0304-3959(98)00154-7

[37] Llorca-Torralba M, Borges G, Neto F, Mico JA, Berrocoso E. Noradrenergic locus coeruleus pathways in pain modulation. Neuroscience 2016;338:93-113.doi: 10.1016/j.neuroscience.2016.05.057

[38] Melzack R. Pain and the neuromatrix in the brain. J Dent Educ 2001;65(12):1378-1382.doi: 
medRxiv preprint doi: https://doi.org/10.1101/2021.11.02.21265820; this version posted November 3, 2021. The copyright holder for this preprint (which was not certified by peer review) is the author/funder, who has granted medRxiv a license to display the preprint in perpetuity. All rights reserved. No reuse allowed without permission.

\section{LOCUS COERULEUS AND CHRONIC PAIN}

[39] Monaco A, Cattaneo R, Mesin L, Ciarrocchi I, Sgolastra F, Pietropaoli D. Dysregulation of the autonomous nervous system in patients with temporomandibular disorder: A pupillometric study. PLoS One 2012;7(9):e45424.doi: 10.1371/journal.pone.0045424

[40] Radloff LS. The CES-D Scale. Applied Psychological Measurement 2016;1(3):385-401.doi: 10.1177/014662167700100306

[41] Roberts AW, Ogunwole SU, Blakeslee L, Rabe MA. The population 65 years and older in the United States: 2016: US Department of Commerce, Economics and Statistics Administration, US ..., 2018.doi:

[42] Rodriguez-Raecke R, Niemeier A, Ihle K, Ruether W, May A. Brain gray matter decrease in chronic pain is the consequence and not the cause of pain. Journal of Neuroscience 2009;29(44):13746-13750.doi: https://doi.org/10.1523/jneurosci.3687-09.2009

[43] Roussel NA, Nijs J, Meeus M, Mylius V, Fayt C, Oostendorp R. Central sensitization and altered central pain processing in chronic low back pain: Fact or myth? The Clinical journal of pain 2013;29(7):625-638.doi: 10.1097/AJP.0b013e31826f9a71

[44] Schoeneborn CA, Heyman KM. Health characteristics of adults aged 55 years and over: United States, 2004-2007. National Health Statistics Reports; no. 16. National Health Statistics Reports, Vol. no. 16. Hyattsville, MD: National Center for Health Statistics, 2009.doi: http://caregiverslibrary.org/Portals/0/National_Health_Statistics_Aug_3_2009_nhsr016.p $\underline{\mathrm{df}}$

[45] Shibata E, Sasaki M, Tohyama K, Otsuka K, Sakai A. Reduced signal of locus ceruleus in depression in quantitative neuromelanin magnetic resonance imaging. Neuroreport 2007;18(5):415-418.doi: 10.1097/WNR.0b013e328058674a 
medRxiv preprint doi: https://doi.org/10.1101/2021.11.02.21265820; this version posted November 3, 2021. The copyright holder for this preprint (which was not certified by peer review) is the author/funder, who has granted medRxiv a license to display the preprint in perpetuity.

All rights reserved. No reuse allowed without permission.

\section{LOCUS COERULEUS AND CHRONIC PAIN}

422 [46] Skljarevski V, Desaiah D, Liu-Seifert H, Zhang Q, Chappell AS, Detke MJ, Iyengar S, Atkinson JH, Backonja M. Efficacy and safety of duloxetine in patients with chronic low back pain. Spine 2010;35(13):E578-585.doi: 10.1097/BRS.0b013e3181d3cef6

425

426

[47] Stubbs B, Binnekade TT, Soundy A, Schofield P, Huijnen IP, Eggermont LH. Are older

[48] Suzuki R, Rahman W, Hunt SP, Dickenson AH. Descending facilitatory control of adults with chronic musculoskeletal pain less active than older adults without pain? A mechanically evoked responses is enhanced in deep dorsal horn neurones following peripheral nerve injury. Brain Research 2004;1019(1-2):68-76.doi:

[49] Taylor BK, Westlund KN. The noradrenergic locus coeruleus as a chronic pain generator. 10.1016/j.brainres.2004.05.108 Journal of Neuroscience Research 2017;95(6):1336-1346.doi: 10.1002/jnr.23956

[50] Vachon-Presseau E, Centeno MV, Ren W, Berger SE, Tetreault P, Ghantous M, Baria A, Farmer M, Baliki MN, Schnitzer TJ, Apkarian AV. The emotional brain as a predictor and amplifier of chronic pain. Journal of Dental Research 2016;95(6):605-612.doi: $10.1177 / 0022034516638027$

[51] Vazey EM, Moorman DE, Aston-Jones G. Phasic locus coeruleus activity regulates cortical encoding of salience information. Proc Natl Acad Sci U S A 2018;115(40):E9439-

442 [52] Vergne-Salle P, Bertin P. Chronic pain and neuroinflammation. Joint Bone Spine 
medRxiv preprint doi: https://doi.org/10.1101/2021.11.02.21265820; this version posted November 3, 2021. The copyright holder for this preprint (which was not certified by peer review) is the author/funder, who has granted medRxiv a license to display the preprint in perpetuity. All rights reserved. No reuse allowed without permission.

\section{LOCUS COERULEUS AND CHRONIC PAIN}

444 [53] Ware JE, Jr., Sherbourne CD. The MOS 36-item short-form health survey (SF-36). I. Conceptual framework and item selection. Med Care 1992;30(6):473-483.doi: https://www.jstor.org/stable/3765916

447 [54] Whitlock EL, Diaz-Ramirez LG, Glymour MM, Boscardin WJ, Covinsky KE, Smith AK.

451 [55] Zhuo M, Koga K, Yamada A, Song Q, Li X, Chen Q, Liu R, Ge J, Zhan C, Furue H. cohort of elders. JAMA Intern Med 2017;177(8):1146-1153.doi: 
medRxiv preprint doi: https://doi.org/10.1101/2021.11.02.21265820; this version posted November 3, 2021. The copyright holder for this preprint (which was not certified by peer review) is the author/funder, who has granted medRxiv a license to display the preprint in perpetuity. All rights reserved. No reuse allowed without permission.

LOCUS COERULEUS AND CHRONIC PAIN

Table 1. Demographics of sample $(n=481)$.

\begin{tabular}{lccccc}
\hline & $\%$ & $n$ & $M$ & $S D$ & Range \\
\hline Age & & & 67.52 & 2.60 & 61.96 to 71.72 \\
Chronic pain & $16.6 \%$ & 80 & & & \\
Race & & & & & \\
$\quad$ Non-Hispanic White & $88.1 \%$ & 498 & & & 8 to 20 \\
Education (years) & & & 13.98 & 2.07 & \\
Medical Comorbidities & & & & & \\
$\quad 17.5 \%$ & 84 & & & 0 to 47.00 \\
$\quad 1$ & $33.1 \%$ & 159 & & & 0.14 to 9.00 \\
$\quad 2+$ & $49.5 \%$ & 238 & & & \\
Depressive Symptoms & & & 6.84 & 6.90 & \\
Opioid Medications & & & 1.36 & 0.88 & \\
$\quad 0$ & $95.0 \%$ & 457 & & & \\
$\quad 1+$ & $5.0 \%$ & 24 & & & \\
\hline
\end{tabular}

Notes. Chronic pain was defined as pain on the SF-36 Bodily Pain Intensity item (Question 22) greater than mild (>3/6) in two or more study waves. Medical comorbidities included major health conditions from the Charlson Index. Depressive symptoms were measured from the Center for Epidemiological Studies Depression scale. Opioid medications were coded as the number of opioid medications recorded during the medical history interview.

Table 2. Main results of general estimating equations predicting rostral $\mathrm{LC}_{\mathrm{CN}}$ with bootstrapping.

\begin{tabular}{lcccc}
\hline Variable & $b$ & $95 \%$ CI & $p$ & $\beta$ \\
\hline Rostral LCcNR (z-score) & & & & -.13 \\
Chronic pain & -.35 & -.62 to -.05 & .042 & -.14 \\
Age & -.04 & -.05 to -.01 & .027 & .01 \\
non-Hispanic White & .05 & -.28 to .38 & .778 & .07 \\
Education (years) & .03 & -.01 to .08 & .150 & -.04 \\
Medical Comorbidities & .03 & -.06 to .09 & .497 & -.05 \\
Depressive Symptoms & -.01 & -.02 to .01 & .483 & .14 \\
Opioid Medication Use & .45 & .07 to .98 & .061 & \\
\hline
\end{tabular}

Notes. $\mathrm{CNR}=$ contrast to noise; LC = locus coeruleus. The rostral LCcNR value was calculated as the average CNR value from the rostral and middle LC regions. The model estimates were conducted using bootstrapping with 1000 resamples. Chronic pain was defined as pain on the SF-36 Bodily Pain Intensity item (Question 22) greater than mild (>3/6) in two or more study waves. Medical comorbidities included major health conditions from the Charlson Index. Depressive symptoms were measured from the Center for Epidemiological Studies Depression scale. Opioid medications were coded as the number of opioid medications recorded during the medical history interview. 
medRxiv preprint doi: https://doi.org/10.1101/2021.11.02.21265820; this version posted November 3, 2021. The copyright holder for this preprint (which was not certified by peer review) is the author/funder, who has granted medRxiv a license to display the preprint in perpetuity.

All rights reserved. No reuse allowed without permission.

LOCUS COERULEUS AND CHRONIC PAIN

Table 3. Main results of general estimating equations predicting caudal LCCN with bootstrapping.

\begin{tabular}{lcccc}
\hline Variable & $b$ & $95 \%$ CI & $p$ & $\beta$ \\
\cline { 2 - 4 } Caudal LCcNR (z-score) & & & & \\
$\quad$ Chronic pain & -.05 & -.20 to .40 & .755 & -.02 \\
Age & -.02 & -.05 to .01 & .065 & -.12 \\
non-Hispanic White & -.13 & -.45 to .18 & .409 & -.04 \\
Education (years) & .02 & -.02 to .07 & .296 & .05 \\
Medical Comorbidities & .03 & -.05 to .11 & .418 & .05 \\
Depressive Symptoms & -.002 & -.03 to .01 & .848 & -.02 \\
Opioid Medication Use & .16 & -.35 to .72 & .524 & .05 \\
\hline
\end{tabular}

Notes. CNR = contrast to noise; LC = locus coeruleus. The model estimates were conducted using bootstrapping with 1000 resamples. Chronic pain was defined as pain on the SF-36 Bodily Pain Intensity item (Question 22) greater than mild (>3/6) in two or more study waves. Medical comorbidities included major health conditions from the Charlson Index. Depressive symptoms were measured from the Center for Epidemiological Studies Depression scale. Opioid medications were coded as the number of opioid medications recorded during the medical history interview.

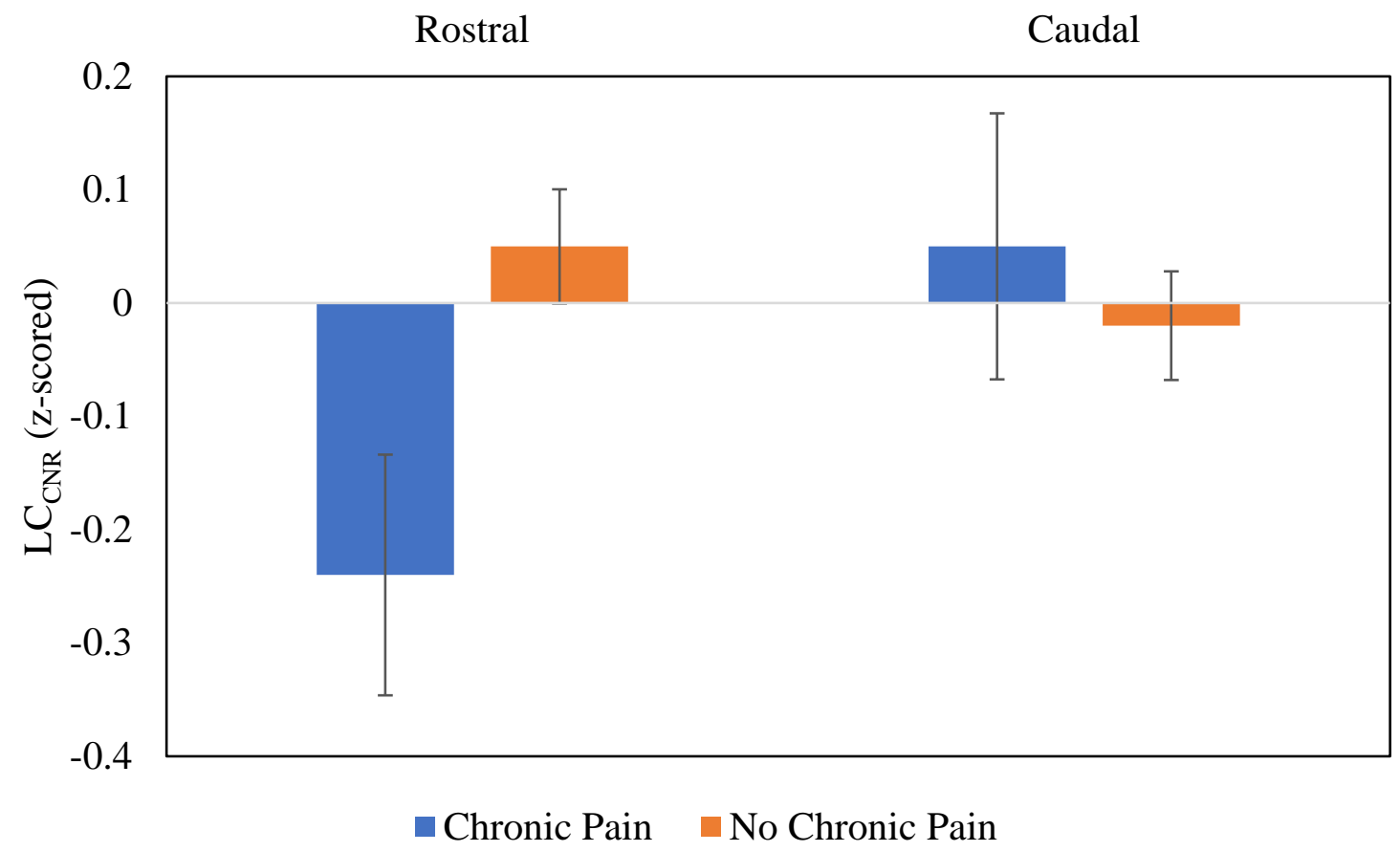

Figure 1. Differences in the rostral and caudal locus coeruleus integrity measured by locus coeruleus contrast to noise ratio (LCCNR) in people with and without chronic pain. On this scale, 0 represents the average LCCNR for the whole sample, units away from 0 represent standard deviations from the sample average. Rostral LCCNR was the average CNR from the rostral and

470 middle LC regions. 